\title{
極短時間内での大型スクラムジェット模型の力計測*
}

\author{
丹野英 幸*1, 小寺正敏*2, 伊藤勝宏*1 \\ 佐藤 和 雄*1, 小室智 幸*2, 高橋政 浩*1
}

\section{Force Measurement of Large-scale Scramjet Model within Short Test Duration}

\author{
Hideyuki TANNO*3, Masatoshi KODERA, Katsuhiro ITOH, \\ Kazuo SATO, Tomoyuki KOMURO and Masahiro TAKAHASHI \\ ${ }^{* 3}$ Japan Aerospace Exploration Agency, Space Propulsion Research Center. \\ 1 Koganesawa, Kimigaya, Kakuda shi, Miyagi, 981 1525 Japan
}

\begin{abstract}
Aerodynamic force measurement technique was developed for large scramjet models within short test time. The technique was based on direct acceleration measurement with miniature accelerometers mounted on a test model. which was suspended with stainless steel wires to make the restorative force negligible. In order to cancel the natural mode of vibrations of the test model. sum averaging signal processing technique was proposed. The technique was applied on drag force measurement of a $3 \mathrm{~m}$ length rectangular duct scramjet in the high enthalpy shock tunnel HIEST. Measurement result was evaluated with a three dimensional Navier-Stokes numerical simulation. The evaluation with numerical simulation showed that the difference between measurement and numerical simulation is less than $5 \%$. It is demonstrated that the technique has sufficient reliability to measure aerodynamic force with time resolution of $350 \mu \mathrm{s}$, which is equivalent to frequency response of $2.88 \mathrm{kHz}$.
\end{abstract}

Key Words: Hypersonic Flow, Computational Fluid Dynamics, Shock Wava, Free Vibration. Experimental Modal Analysis

\section{1 はじめに}

自由ピストン型衝撃風洞は, 従来型風洞では模擬で きない数百〜数千気圧の淀み点圧力, 数千度の淀み点 温度条件を生成できることから, 大気圈再突入体周り の流れ, スクラムジェット内部流机等, 反応現象を伴 う超高速流れの地上試験に用いられる ${ }^{(1)}$. 宇宙航空研 究開発機構が保有する高温衝撃風洞 HIEST ${ }^{(2) 3)}$ は, 大 型の自由ピストン型衝撃風洞設備であり，世界でも最 大規模である全長 $3 \mathrm{~m}$ の大型スクラムジェット模型を 用いた燃焼試験が可能である. 気流条件にも依存する が, HIEST の試験時間は数ミリ秒〜十数ミリ秒程度

\footnotetext{
* 原稿受付 2004 年 6 月 11 日

*1 正員, 宇宙航空研究開発機構宇宙推進技術共同センター (画981-1525 角田市君萱小金沢 1)

*2 宇宙航空研究開発機構宇宙推進技術共同センター.

E-mail : tanno@kakuda.jaxa.jp
}

と従来型の風洞と比べ短い。従って，スクラムジェッ トエンジンの性能評価として特に重要となる推力計測 において, 従来風洞で用いられてきたロードセルによ る力計測法では時間必答性が悪く, 計測精度の確保が 困難である.

·方, 衝撃風洞による空力試験を目的に, 橔短時間 力計測技術は1960件代から多く研究され，数々の妇

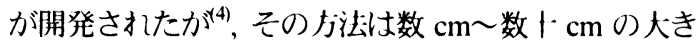
さの小型模型への適用に止まり, HIEST 試験に供され る大型模型での力計測奏験の報沶は例が無い。

本研究では, HIEST への適用を目的とした大型スク

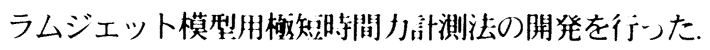
この論文では，計測原理，検走結果及び全長 $3 \mathrm{~m}$ の大 型スクラムジェット模型を供試体とした HIEST での 
抗力計測試験結果を述べる. また, 数值シミュレーシ ヨンによって評価・解析を行い, 本計測法の精度・信 頼性を検討した。

\section{2 力計测法}

風洞試験に於いて力計測系は図 1 に示される単純な モデルとして表すことが可能である.このとき, F は 負荷, $\mathrm{m}$ は模型慣性質量, $\mathrm{k}$ は支持装置(スティング等) の剛性を示す.

大型模型を用いた場合，必然的に $\mathrm{m}$ が大であるため $\left(\mathrm{m}\left(\mathrm{d}^{2} \mathrm{x} / \mathrm{dt}^{2}\right)>>\mathrm{kx}\right)$, 弾性力 $\mathrm{kx}$ をできるだけ無視できる 状態として, 模型の加速度を計測し，力を算出する方 法が合理的となる. 抣拘束法(5), 加速度天秤法(6)と一般 的に呼ばれる力法は, スティング等の剛性の高い支持 法の替わりに，模型をワイヤ，スプリング等の剛性が 低い方法で支持する. 模型に負荷される空力荷重は, 模型に取り付けた小型加速度計出力と模型質量の積か ら単純に算出することが叮能である.しかしこの方法 の適用実績は, 全長数 $\mathrm{cm}$ 数 $+\mathrm{cm}$ の小型の模型にと どまる.これは, 模型が大型化すると, 十分な模型剛 性の確保が困難となり, 模型の固有振動数が出力信号 に振動成分として重量され，此確な計測を妨げるため である. 振動成分の影響を除くために, 移動平均によ り平滑化するち法は, 時間分解能とトレードオフの関 倸にあるため, 短い試験時間には安易に適用すること はできない。

そこで本研究では, 2 個の加速度計を用いて極めて 容易に固有振動の影響を回避する方法を試みた。般 的にスクラムジェットはダクト形状であり, 模型軸方 向振動は図 2 に示される固有振動モ一ドを有する. 図 2 の a, b 点では, 2 次モ一ドが節となり振幅は 0 となる が, 他の振動モ一ドが残仔する.しかし, a, b 点では奇

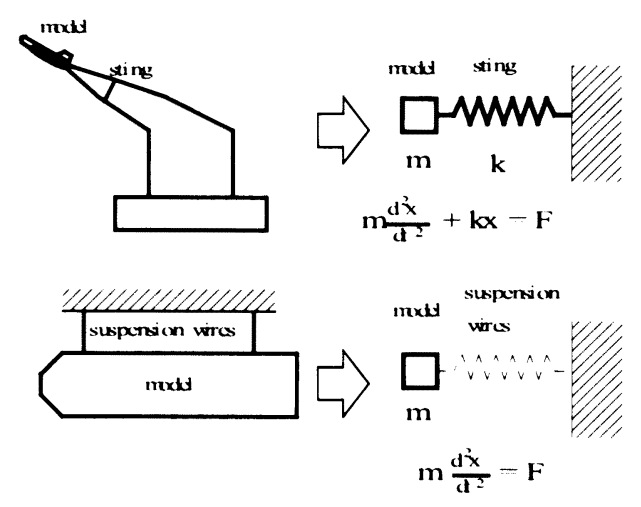

Fig. 1 Model of force measurement system
数次モ一ドの振幅は同じで位相が互いに逆となるため, $\mathrm{a}, \mathrm{b}$ の相加平均を行うと奇数次の高次振動成分を打消 すことが理論上可能である.

HIEST での大型スクラムジェット力計測試験では, 時間分解能が $2 \sim 3$ 百 $\mu \mathrm{s}$ 程度であれば, 推力性能評価 用としては十分である. 今回用いる大型スクラムジェ ット模型では, 4 次モ一ドの以上の振動成分 $(2.88 \mathrm{kHz})$ を, ローパスフィルタで除去し, 時間分解能として $350 \mu \mathrm{s}$ を確保することを狙った. 次に, この原理を大 型スクラムジェット模型に応用し，実際に計測を試み る.



Fig. 2 Vibration modes of test scramjet model

\section{3 大型スクラムジェット模型}

計測法の評価に用いられた大型スクラムジェット 模型(以後M12 スクラムジェット)は超高速域での燃焼 特性を研究する目的で設計された. 模型全長は $2.9 \mathrm{~m}$, インレット入り口断面W $200 \times \mathrm{H} 250 \mathrm{~mm}$, 重量 $289 \mathrm{~kg}$ で ある. 模型は側板圧縮型インレット及び側板膨張型の ノズルを有し, 燃焼器は単純な矩形ダクト構造を持つ. 燃料噴射用に, 左右側板ステップ背後にそれぞれ 11 個 の噴射口（ $\phi 3.0 \mathrm{~mm})$ が合計 22 個設けられており, 燃 料であるガス水素がこの噴射口より，スクラムジェッ 卜模型後方へ平行噴射される. 尚, ガス水素は高速燃 料噴射装置(れによって制御され，通風時の短時間のみ 噴射される.

模型概略を図 3 に示す. 模型はボルトによる組み立 て構造とした. 正確な計測を妨げる高周波振動の発生 を防ぐため, 本模型では, 構造部材の構成数量をでき るだけ減らし, 部材肉厚 $50 \mathrm{~mm}$ のアルミニウム合金 (A7075)無垢材より製作することで, 風性確保を狙っ た. また, 部品間の結合剛性確保のために, 側板は軸 方向にM14 ボルト 2 本, 上下左右併せて 8 本で結合す る設計とした. 模型は支持拘束が無視できるものとす るために, 直径 $2 \mathrm{~mm}$ (素線数 $7 \times 7$,素線径 $0.23 \mathrm{~mm}$ )の 


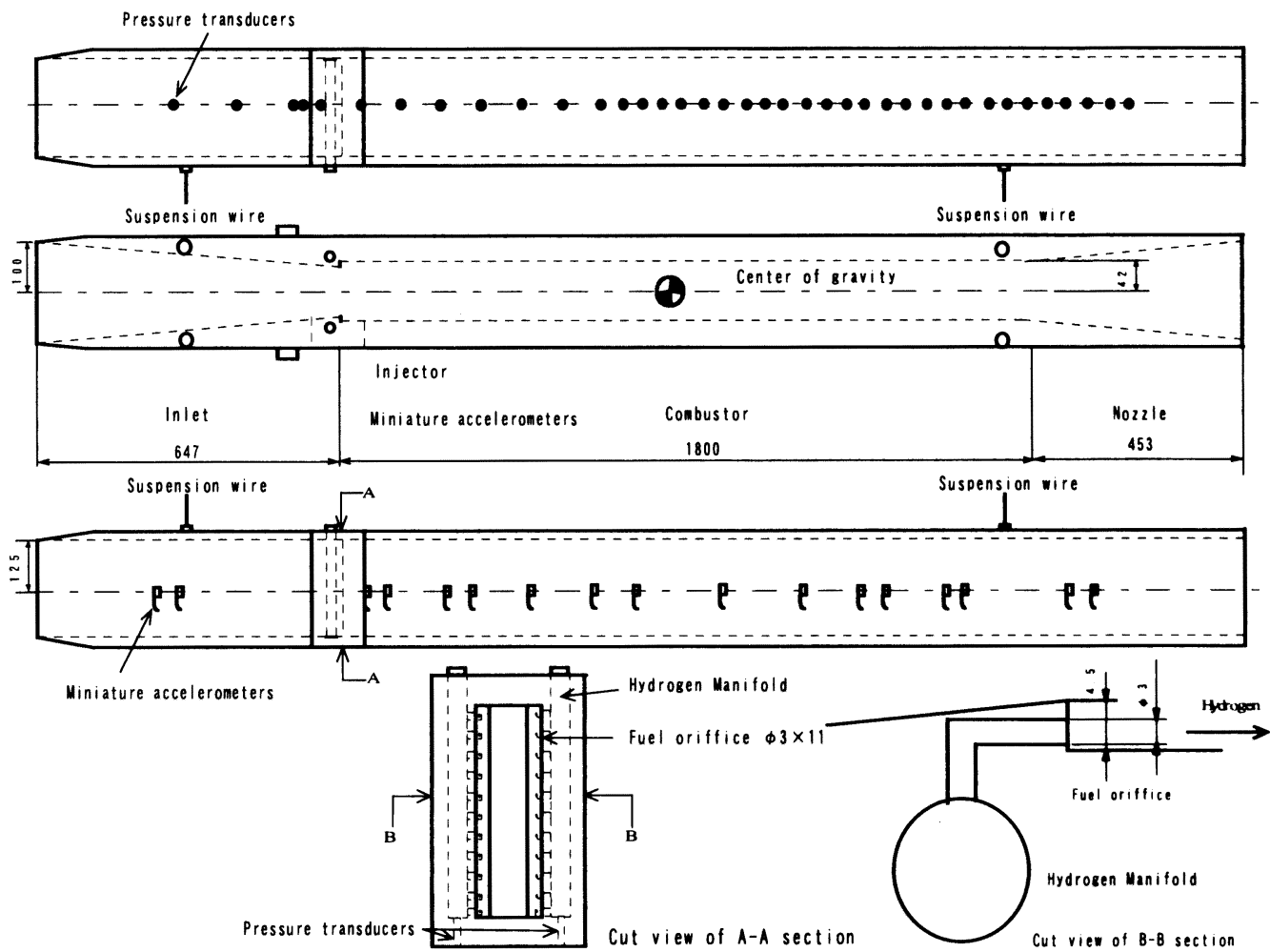

Fig.3 Schematic of the M12 scramjet test model

SUS304 製ワイヤ 4 本で風洞試験部天井から吊され た.

後述する数值シミュレーションの評価のために模 型右側板内面には半導体ひずみゲージ型圧力トランス デューサ (Entran 社製 EPI-58, 共振周波数 $500 \mathrm{kHz}$ ) を 38 個取り付け, 圧力分布の計測を行った. 力計測に は圧電型小型加速度計(PCB 社製 352C65, 共振周波 数 $50 \mathrm{kHz}$ )を用い, 模型左側板外面の中心線上軸方向 に 17 個取り付けた. 模型先端を原点とした加速度計 の軸方向位置を表 1 に示す.これらのセンサ出力は, $\mathrm{A} / \mathrm{D}$ 変換器内蔵トランジェントメモリ (System

Table.1 Location of accelerometers

\begin{tabular}{|r|r|r|r|}
\hline No. & Location(m) & No. & Location(m) \\
\hline 1 & 0.2828 & 10 & 1.6428 \\
2 & 0.3428 & 11 & 1.8428 \\
3 & 0.7828 & 12 & 1.9828 \\
4 & 0.8428 & 13 & 2.0428 \\
5 & 0.9828 & 14 & 2.1828 \\
6 & 1.0428 & 15 & 2.2428 \\
7 & 1.1828 & 16 & 2.4828 \\
8 & 1.3828 & 17 & 2.5428 \\
9 & 1.4428 & & \\
\hline
\end{tabular}

Design Service 社製 Grasper Model-1000, サンプリ ング周波数 $500 \mathrm{kHz}$, 精度 14bit)によってデジタルフ アイルとして記録される. 力計測の為の振動処理, 後 述するローパスフィルタリングは試験後, コンピュー タ上で実施した.

\section{4. 検定試筑}

\section{1 打整検定試篗}

時間応答を改善する信号処理法として用いられる 逆盢み込み演算処理法(8)(9)では, 処理に必要な計測系 の周波数応答関数を打摮試験によって予め取得する. 従って, 打撃試験精度は計測精度に直接影響を与える ため, 精度の高い打撃試験が求められる. 本方法では, 打撃試験に要求されるのは, 軸方向の主要な振動の励 起のみであり, いわゆる技量的要求が無いため, 簡便 に行うことが可能である. ここでは，一般的なインパ クトハンマー（PCB 社製 086C03）を用いて打撃試験 を行った. 図 4 には打撃試験によってインパルス入力 を与え, 励起させた模型の縦方向振動の周波数特性を 代表例として示す. 図中実線及び点線は，それぞれ図 2 に示される 1 次振動乇一ドが節となる $\mathrm{c}$ 点及び 2 次 
振動モ一ドが節となる $\mathrm{a}$ 点に設置された加速時計の振 動特性を示す. 振動は $720 \mathrm{~Hz}$ の周波数を持つ基本固 有振動モ一ドとその高調波が主成分であった. 加速度 計の取り付け位置に対する各振動モ一ドの振幅を図 5 に示す. 図中の振幅は, 模型先端に最も近い位置(先端 より $283 \mathrm{~mm}$ )に取り付けられた加速度計振幅值で無次 元化した. 図より, 信号処理に用いる加速度計は, 2 次 振動モードの節の部分である a 点(先端より $783 \mathrm{~mm}$ ) 及び b 点(先端より $2183 \mathrm{~mm}$ )に選定した. 図 6 に打撃



Fig. 4 Impulse response of accelerometers at point a and at point $\mathrm{c}$

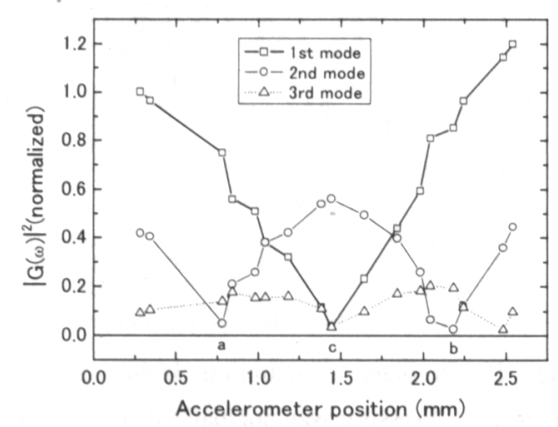

Fig. 5 Vibration characteristics of the test model



Fig.6 Impulse response of accelerometers at point a and at point $b$
試験で得られた $\mathrm{a}$ 点, $\mathrm{b}$ 点の加速度計出力を示す. 両点 での加速度計出力は軸方向の基本振動周波数である $720 \mathrm{~Hz}$ の振動を示し, 振幅は同等で, 位相が逆である.

\section{2 噴射検定試験}

力計測法の簡易的な検定のために，M12 スクラムジ エット模型の水素噴射試験を行い，噴射によって発生 する推力計測を行った. 図 7 に水素マニホールド圧力 $\mathrm{Pm}=4.5 \mathrm{MPa}$ の条件で噴射した際の推力履歴を示す. 図 中点線は $\mathrm{a}$ 点に設置された加速度計出力, 細い実線は $\mathrm{b}$ 点に設置された加速度計出力である. 太い実線は $\mathrm{a}$, b 点出力を相加平均で処理した值を示す. 水素噴射に よって発生する力は，風洞試験に比べ絶刘值が小さい， また図中の水素マニホールド圧力履歴に示される通り, 噴射開始から圧力が定常となるまで $4 \mathrm{~ms}$ 程度と遅いた め，噴射によって模型に与えられる力の成分は低周波 であり, $720 \mathrm{~Hz}$ の模型の固有振動は強く励起されない. しかし，点線と破線に重畳している $720 \mathrm{~Hz}$ の振動成分 は, 相加平均処理により十分低減されていることが確 認できた.

同様に $\mathrm{Pm}$ を変化させ計測した推力増分 $\Delta \mathrm{F}$ を図 13 中に記号 $\square$ で示す。図中点線は水素が噴射口より音 速で噴射されることを仮定して予測した理論值を示す。 計測值と理論值はほぼ一致し, 最小自乗法で得られた 計測值と理論值の $\Delta \mathrm{F} / \mathrm{Pm}$ の傾きの差は $5 \%$ であった.

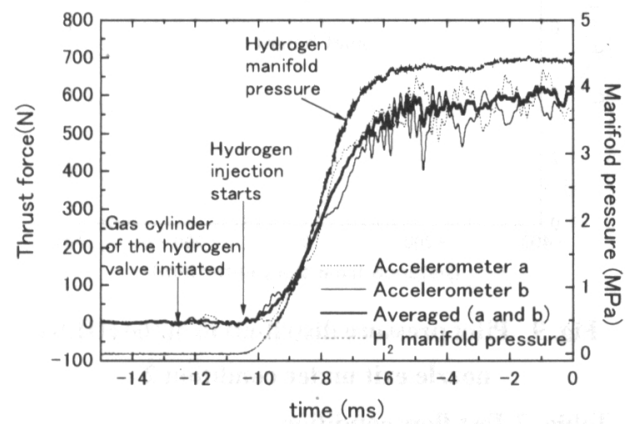

Fig. 7 History of measured thrust produced with hydrogen injection

\section{5. 風洞試験}

\section{1 風洞試験条件及び数值シミュレーション}

続いて，本計測処理法を風洞試験に適用する，風洞 試験は自由ピストン型衝撃風洞HIEST で行った. 試験 気流動圧は風洞ノズル貯気槽圧力 $\mathrm{P}_{0}$ とほぼ比例するた め, $\mathrm{P}_{0}$ を 19，36，59MPa と変化させ，模型に負荷され る空力荷重を変えた 3 条件で風洞試験を行った，気流 
エンタルピはM12 スクラムジエット模型の設計条件で ある飛行マッハ数 12 相当の $\mathrm{H}_{0}=7.5 \mathrm{MJ} / \mathrm{kg}$ で固定した. 気流条件は計測された衝撃波管端圧力, 衝撃波速度よ り化学平衡反応コード(10), 及び軸対称 Navier-Stokes コード(11)によって算出した(表2). 図8に各条件のピト 一圧力時間履歴を示す. $\mathrm{P}_{0}=36 \mathrm{MPa}, \mathrm{P}_{0}=59 \mathrm{MPa}$ において, 風洞運転条件が若下アンダーテイラード条件で有るた め, 始動時における Pitot 圧力の変動は大きいが, $\mathrm{t}=2 \mathrm{~ms}$ 以降に静定し, $\mathrm{P}_{0}$ の減少に伴い, Pitot 圧力が低 下する $\mathrm{t}=6 \mathrm{~ms}$ までほぼ一定值を示す，従って, 試験時 間はPitot 圧力がほぼ定常となる 3〜 5ms とした。

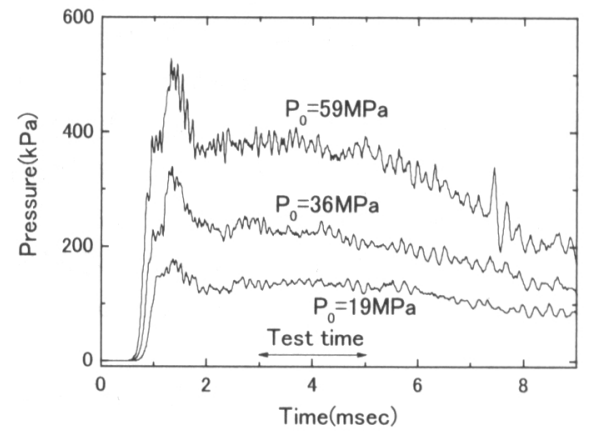

Fig. 8 Free stream Pitot pressure histories under condition 1,2 and 3

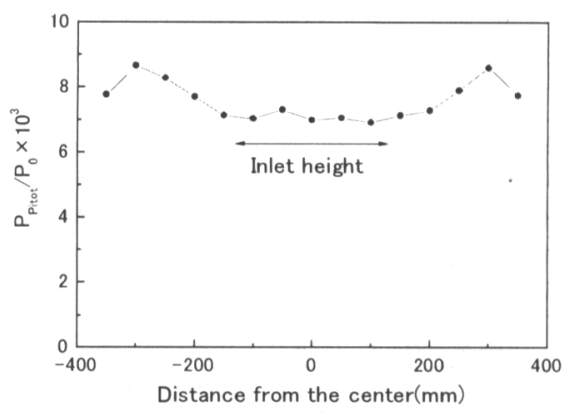

Fig. 9 Pitot pressure distribution at the HIEST nozzle exit under condition 2

Table. 2 Test flow condition

\begin{tabular}{|l|c|c|c|}
\multicolumn{1}{|c|}{ Condition } & 1 & 2 & 3 \\
\hline \hline $\mathrm{P}_{0}$ Stagnation pressure(MPa) & 19 & 36 & 59 \\
$\mathrm{H}_{0}$ Stagnation enthalpy(MJ/kg & 7.2 & 7.4 & 8.3 \\
$\mathrm{~T}_{\infty}$ Temperature(K) & $7.3 \times 10^{2}$ & $7.7 \times 10^{2}$ & $9.0 \times 10^{2}$ \\
$\mathrm{P}_{\infty}$ Pressure(kPa) & 2.6 & 5 & 8.5 \\
$\rho_{\infty}$ Density $\left(\mathrm{kggm}^{3}\right)$ & $1.3 \times 10^{-2}$ & $2.3 \times 10^{-2}$ & $3.3 \times 10^{-3}$ \\
$\mathrm{~V}_{\infty}$ Velocity $(\mathrm{km} / \mathrm{s})$ & 3.5 & 3.6 & 3.8 \\
$\mathrm{M}_{\infty}$ Mach number & 6.6 & 6.5 & 6.4 \\
$\mathrm{Re}$ Unit Re number $(\mathrm{l} / \mathrm{m})$ & $1.3 \times 10^{6}$ & $1.3 \times 10^{6}$ & $3.1 \times 10^{6}$ \\
\hline
\end{tabular}

また，本風洞試験に先立つてノズル気流一様性を計 測した. 図 9 にPitotレークを用いて計測したノズル 出口の主流 Pitot 圧力分布を示す. M12 スクラムジェ ットインレット入り口断面の範囲において気流は十分 一様であり, 圧力分布の変化は土3\%以下であった.

模型内流孔解析及び計測結果の評価には非構造格 子 3 次元 NS 数值シミュレーションコード(12)を用いた. ここで計算格子点数は 250 万点である. 表 2 の主流 Re 数から, スクラムジェット内部流㧈はほぼ乱流と考え られる ${ }^{(13)}$ ため, 計算には全域乱流を仮定し, 乱流モデ ルには, Spalart-Al lmarous ${ }^{(14)}$ を用いた。

\section{2 抗力変化}

図 10 は 3 つの風洞試験条件で計測されたスクラム ジェット内圧力分布を数值シミュレーション結果と併 せて示す.インレット先端で発生した衝撃波はスクラ ムジェット燃焼器内で反射を繰り返し, 波状の圧力分 布を示した. 数值シミュレーション結果と計測值は圧 力值, 衝撃波反射位置においてほぼ合致しており, 本

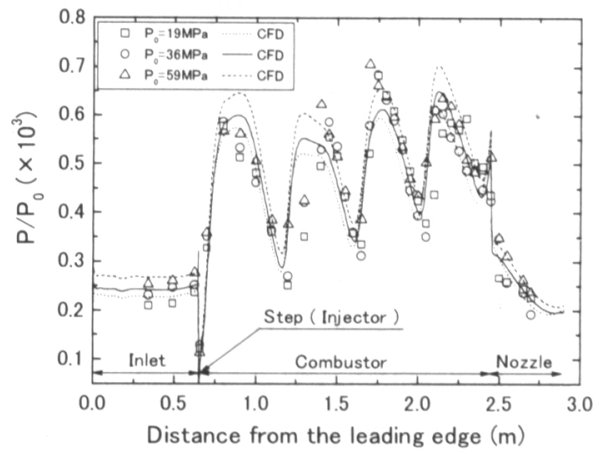

Fig. 10 Pressure distribution inside the M12 scramjet. Pressure was normalized by stagnation pressure

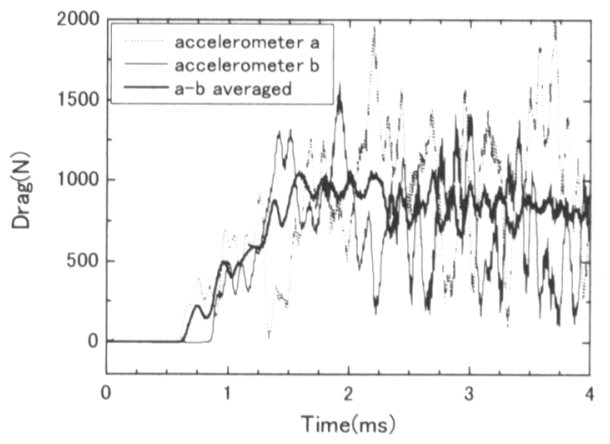

Fig. 11 Force history measured at point b, at point $\mathbf{c}$ and $\mathrm{b}-\mathrm{c}$ averaged under condition 2 . 
数值シミュレーションはスクラムジェットエンジン内 流れを十分に模擬しているものと考元られる.

図 11 は $\mathrm{P}_{0}=36 \mathrm{MPa}$ で計測された軸力時間履歴を示 す. 図中の点線は $\mathrm{a}$ 点, 波線はb 点の加速度計出力を表 す. 風洞試験では模型に負荷される空力荷重が大きく, 燃料噴射試験での入力負荷に比べ急峻に立ち上がるた め, 高い周波数帯が励起されることから, 燃料噴射試 験に比べて振動の振幅は大きい. 振動処理方法は燃料 噴射試験之同梯に相加平均処理を行い, 実線で示され る抗力処理結果を得た. 基本振動およびその高調波に よって激しい振動を示す $\mathrm{a}$ 点, $\mathrm{b}$ 点の出力值は本処理法 によってうち消され，4 次の高調波成分 $(2.88 \mathrm{kHz})$ の みが残る.この振動成分は, 商用解析ソフトウェア



Fig. 12 Measured drag force under different $P_{0}$ condition

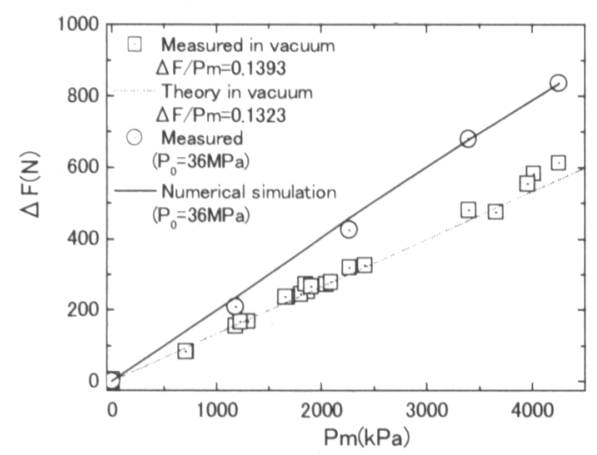

Fig. 13 Thrust variation with manifold pressure

Table. 3 Drag reduction effect on thrust increment

\begin{tabular}{|c|c|c|c|c|c|}
\hline $\begin{array}{l}\mathrm{Pm} \\
(\mathrm{kPa})\end{array}$ & $\begin{array}{l}\dot{m}_{H 2} \\
(\mathrm{~g} / \mathrm{s})\end{array}$ & $\begin{array}{l}\Delta \mathrm{F} \text { in } \\
\text { vacuum } \\
(\mathrm{N})\end{array}$ & $\begin{array}{l}\Delta F \text { in } \\
\text { free } \\
\text { stream }(N)\end{array}$ & $\begin{array}{l}\Delta F_{\text {freestream }} \\
-\Delta F_{\text {vacuum }} \\
(N)\end{array}$ & $\begin{array}{l}\text { Friction } \\
\text { reduction } \\
(\mathrm{N})\end{array}$ \\
\hline 0 & 0 & 0 & 0 & 0 & 0 \\
\hline 1179 & 74 & 164 & 234 & 70 & 24 \\
\hline 2262 & 141 & 315 & 458 & 143 & 67 \\
\hline 3397 & 212 & 473 & 676 & 203 & 98 \\
\hline 4251 & 266 & 592 & 834 & 242 & 115 \\
\hline
\end{tabular}

(OriginLab 社製 Origin7.5)を用い, 遮断周波数を $2.88 \mathrm{kHz}$ としたデジタルフィルタにより除去した. 除 去結果を図 12 の抗力履歴として示す. 図 12 には同様 な処理を $\mathrm{P}_{0}=19 \mathrm{MPa}, \mathrm{P}_{0}=59 \mathrm{MPa}$ の抗力計測值に適用し た結果も併せて示した. また, 図中に示される直線は それぞれの条件で行った数值シミュレーションによる 予測值である. 計測值は数值シミュレーションの值よ り最大 $5 \%$ 過大であった。

\section{3 水素噴射による抗力減少}

次に水素噴射を伴った風洞試験を行い, 模型に発生
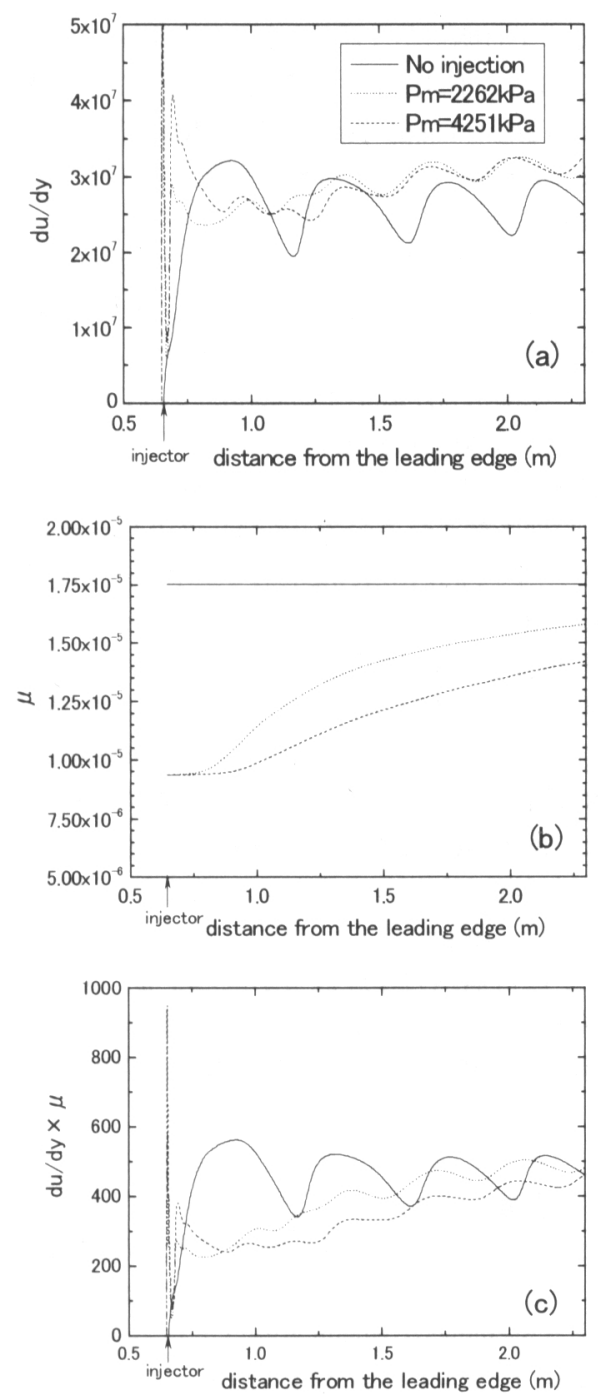

Fig. 14 Friction parameter variation along the axial direction. (a) du/dy, (b) $\mu$ and (c) du/dy $\times \mu$ 
した軸力を計測した. 今回の試験条件の様に超高速流 れ場で燃焼を伴った場合は, 数值シミュレーションの 信頼性が未だ不足している. そのため, 試験気流には 窒素を用い, 未燃条件での試験を行った. 風洞ノズル 貯気槽圧力は $\mathrm{P}_{0}=36 \mathrm{MPa}$ に固定し, 水素マニホールド 圧力 $\mathrm{Pm}$ を 0 から $4300 \mathrm{kPa}$ まで変化させた. 図 13 に風 洞試験結果を○, 同条件での数值シミュレーション結 果を実線として示す.このとき, 図中で示される推力 増分 $\Delta \mathrm{F}$ は噴射無し試験での計測抗力と噴射有りでの 計測抗力の差として定義した. 計測值と数值シミュレ ーションの差は 5\%以内であり, 図 12 に示した無噴射 条件試験との有意な差は認められなかった。

図13より明らかな通り，窒素気流中への水素噴射に よる $\Delta \mathrm{F}$ は同じ噴射圧力での真空中への水素噴射によ る $\Delta \mathrm{F}$ に比べ 1.4 倍である. この原因を探るため, 数值 シミュレーションによる解析を行った. 表 3 に数值シ ミュレーションによって算出された推力増分への摩擦 抗力寄与の内訳を示す. 真空中への噴射之窒素気流中 への噴射の差 $\left(\Delta F_{\text {Free stream }}-\Delta F_{\text {Vacuum }}\right)$, 即ち抗力減少は, 摩擦抗力減少による寄与が $34 \%$ 48\%であった.ここ では, 摩擦抗力が低下する原因について数值シミュレ ーションで更に検討を行った.

摩擦抗力は壁面近傍の速度勾配(du/dy)および粘性係 数 $(\mu)$ に影響されるので, その 2 つのパラメー夕に注 目する. 図 14(a),(b), (c)は水素マニホールド圧力 Pm を $0 \mathrm{kPa}, 2262 \mathrm{kPa}, 4251 \mathrm{kPa}$ と変化させた条件において, 平 行燃焼器内での速度勾配, 粘性係数およびその積 $(\mathrm{d} u / \mathrm{dy} \times \mu)$ を示す. 図 14(a)に示される様に, 水素噴射 を行つた場合, 速度分布の周期的変動振幅が減少し, 燃焼器全体の平均值は増加した. 一方, 図 14(b)に示さ れる粘性係数 $(\mu)$ は, 水素噴射量の増加に伴い, 主流 中の水素濃度が増加するために低下する. 粘性係数と 速度勾配の積 $(\mathrm{du} / \mathrm{dy} \times \mu)$ は図 14(c)に示される通り減 少し, 燃焼器内の摩擦抗力が低下する. 以上から, 摩 擦抗力の減少は水素噴射によって, 燃焼器内気流中の 水素濃度が増加し, 粘性係数の低下が原因と推定され る.

\section{6. 結論}

小型加速度計による極短時間での空力計測法を全長 $3 \mathrm{~m}$ の大型スクラムジェット模型の力計測試験に適用 した. 2 箇所同時の加速度計測により, 模型自体の固有 振動を 3 次モードまで打ち消すことで, 時間解像度 $350 \mu$ 秒(応答周波数 $2.88 \mathrm{kHz}$ )を保証した. 校正試験と して行った真空中への水素噴射試験では, 計測された 発生推力が理論值に比べ $5 \%$ 過大であった. また, 大
型衝撃風洞 HIEST 風洞での抗力計測試験に执いて, 計 測值は数値シミュレーションに比べ $5 \%$ 過小であった. HIEST を用いた抗力計測試験では, 窒素試験気流中 への水素噴射試験も併せて行い，水素噴射による摩擦 抗力低下が確認された。. 数値シミュレーションによる 解析では, 燃焼器内匃流中の水素濃度増加により, 粘 性抵抗が減少することが原因と推定された。

\section{謝辞}

本研究の実施，論文の作成にあたつて、試験の実 施, デー夕処理を協力して頂いた航空宇宙技術振興財 団の前原卓哉さん, 成用智昭さん, 藤村健太郎さん， 及び論文作成を手伝って頂いた玉山薫さんに感謝致し ます.

\section{参考文献}

(1) Paull A., AIAA 99-2450(1999)

(2) 伊藤他 10 名, 航空宇捕学会誌, 第 49 巻, 第 572 号 (2001), pp. 199-207


(2002), pp. 1-6

(4)Bernstein L., A GARDograph,

AGARD-AG-214(1975)

(5) Sheeran W. J., et. al, ICIASF '69 records, pp. 190-197 (1969)

(6) Reddy N. M., Proc. $15^{\text {th }}$ Int. Symp. Shock tubes and Waves, pp. 358-362 (1985)

(7) Tanno H., et. al, ISTS 2000-a-15 (2000)

(8) Sanderson SR and Simmons JM, AIAA J. 29:2185-2191(1991)

(9) Tanno H., et. al, Rev. Sci. Inst. Vol. 75, No. 2(2004)

(10) Prabhu RK and Erickson WD, NASA TP-2792 (1988)

(11) Takahashi M et al., , AIAA 01-3681 (2001).

(12) Kodera M., et. al, AIAA 2000-0886 (2000)

(13) Goyne C. P., et. al, Proc. 20 Int. Symp. Shock tubes and Waves, pp. 1125-1130(1997)

(14) Spalart P. R. et. al, AlAA-92-0439 (1992). 